MedieKultur | Journal of media and communication research | ISSN 1901-9726

Article

\title{
The public of media events
}

\section{Christian Morgner}

MedieKultur 2011, 50, 143-159

Published by SMID | Society of Media researchers In Denmark | www.smid.dk The online version of this text can be found open access at www.mediekultur.dk

This article focuses on the growing importance of large-scale events and their central role in a globalised media world in relation to public reactions and public involvement.

The peculiar structure of such events requires a different understanding of mass communication and its audience. Therefore, the audience is further examined with regard to its impact on and inclusion in the media itself. Consequently, questions are raised as to how the public is incorporated, the form this inclusion takes and the effect that this has on the audience's participation.

The article examines different types of semantic inclusion, with a focus on emotional reactions towards three different media events: the Titanic disaster, the assassination of John F. Kennedy, and the death of Princess Diana.

\section{The public of media events ${ }^{1}$}

There has been a growing awareness in the social sciences concerning large-scale events and their central role in a globalised media world (cf. Thompson, 1995, p. 107 ff.). Recent terrorist attacks in particular have initiated a substantial amount of research regarding these phenomena. When covering these attacks, the media depict them as disruptive and allencompassing, with an inclusive and self-referential procession (cf. Morgner, 2008). Mass 
media or mass communication is usually understood as the transmission of information from a sender to a receiver, with the transmission furthermore reaching an unknown and vast audience. The concept of this "transmission" may vary only in its details. Examples include the plain stimulus-response approach, the two-step flow of mass communication, gratification approaches, or semiotic descriptions, which currently dominate the modern understanding of mass media. ${ }^{2}$

If one applies this understanding to media events, it seems that a great deal of the structuration of such phenomena is left untouched: the complex referential system between the messages, the constant looking back or loop of the message itself, the repetition of virtually the same information, and the dense and compact nature of the material given. ${ }^{3}$ Therefore, another direction of the flow of media messages is suggested in this article, one that addresses the media messages themselves: "in the sense that media messages [...] refer to other media messages" (Thompson, 1995, p. 110). If this direction is changed, one must question what would happen to the alleged audience. The common approach of mass communication as a method of information transmission suggests this information is delivered to the reader or people watching, or in other words, the information is delivered to their minds. The approach proposed in this article does not refer to the audience as a mental construct and thus excludes the audience from the succession or circulation of media messages. ${ }^{4}$ The audience is, somehow, a psychic environment for that succession (cf. Luhmann, 1990).

In contrast to this approach, classic investigations of audiences study how they react to the impact of an event, addressing the audience from a socio-psychic perceptive (see Molotch \& Lester 1974; Kepplinger \& Roth, 1979; Steenveld \& Strelitz 1998). The first study explaining an event from a social-psychological point of view was Hadley Cantril's (1960) "The Invasion from Mars", which depicted a mass panic in relation to a notorious radio play. Respondents were questioned why they felt afraid or panicked. The radio play as a media event is not described, but rather, the impact of the event is, thus defining it as a key event (cf. Kepplinger \& Habermeier, 1995). This approach has a long tradition in communication research. Prior to the study of Kepplinger and Habermeier, Bernhard Berelson (1949) formulated such a definition in the early stages of communication science. Events are in these studies described because of their influence and impact on public opinion. The media, the event and their audience are separate parts; neither co-existence nor mutuality were mentioned with any frequency.

Another stream of media research, known as media rituals, focuses on this particular gap (cf. Curran \& Liebes, 1998). Daniel Dayan and Elihu Katz (1990) specifically examine this theme. Media events are analysed through their ritualistic qualities, providing relief and order in times of crises. The authors thus analyse a specific type of media event: those which are consciously integrative and constructed with a view of orchestrating a consensus, as in the case of media ceremonies like Princess Diana's wedding or John F. Kennedy's funeral. The public is merely understood as a witness of such live broadcasts; their emotional response 
is part of the disrupting quality of the event, but it is not further examined in relation to its impact and inclusion in the media itself.

Research concerning the effects on society by mediated catastrophes and disasters tends to focus on occurrences such as tornadoes, floods or earthquakes, and it is directed towards the physical and psychological consequences of those affected at the locations concerned. ${ }^{5}$ A catastrophe is here defined as "a great calamity, an event occurring with serious consequences, like the harming or loss of life for humans and animals, material damage, and large-scale destruction" (Schenk, 2007, p. 12). Especially since the increase in terror attacks in recent years, it has become clear that the worldwide resonance incited by these events is not solely connected with people who are directly affected. Although these attacks often have been associated with limited destruction and death (as compared to that wrought by natural disasters), the extent and intensity of public reactions to them have been similar to those following natural catastrophes.

In contrast to these studies and their approaches, this article assumes that another approach is necessary, one in which the succession of media messages is debated and the mass media plays a central mediating role. This seems to be justified, as the media events concerned are reported and narrated within their realm; thus, the public at large can experience and visualise the event as other viewers do. Therefore, this witnessing itself becomes a generating quality of a media event, it is part of the self-reproducing structure of the media event. The task of this article is therefore to describe media events from the perspective of an interactive process between the semantic inclusion of audience reactions within media texts/visualisations and audience perceptions and reactions. This approach raises three specific questions: a) in regards to semantic inclusion, how does the public, within the framework of such events, become included in the flow of media messages surrounding such events? b) in regards to emotional reactions, i.e., co-presence, what forms of participation result from the public's inclusion and c) in terms of function, what effects do these forms of participation have?

\section{Methodological considerations and case selections}

The answers to these questions can be ascertained through a close examination of three different large-scale events (the Titanic disaster, the assassination of John F. Kennedy and the death of Princess Diana of Wales) and three different regions (the U.S., Germany and Malaysia). The reason for these selections is motivated by the methodological approach of Grounded Theory (cf. Glaser \& Strauss, 1967). Because this article is concerned with the development of a general framework, it is important to cover a variety of different events and thus to reveal the most basic concepts. Instead of comparing haphazardly a large number of cases, like one would have to do when using certain quantitative techniques, this study draws on the modus of comparison used in Grounded Theory. The generation of data is thereby mainly led by a minimal and a maximal contrast. ${ }^{6}$ On the one hand, the 
chosen cases are of similar appearance and shape; all had a large-scale impact and are still occasionally remembered.' On the other hand, they occurred in different historical settings, thus relying on different states of media technology and organisation. As all of the events were heard and watched by audiences outside the countries in which they occurred, it seemed important to include other cultural regions in this research, as this suggested further contrasting possibilities. The three cases represent almost three stages in the history of the mass media. The Titanic disaster occurs in the age of the printing press and the mass distribution of newspapers before the advent of radio or television. The assassination of John F. Kennedy is marked by the use of new media like television. The death of Princess Diana, the most recent event described in this article, occurs in a time of satellite television, new recording technologies, and the early stages of the digital dissemination of information, known as the "new media". The three regions selected parallel these historical states of the mass media, with the U.S. as the most advanced region, Germany in the middle, and the lowest density and use of such technologies in Malaysia/Singapore. The three regions also represent different cultural areas of the world, with different preferences, programme structures etc.

The historical dimension of the three cases allows the evaluation of the impact of different media technologies. This seems to be critical as the occurrence of large-scale events, within a short time, is very often limited to the use of new media technologies, which highlight speed and instant communication. I have shown elsewhere that the media of mass dissemination play a constitutive role for all the media events covered in this article, but are not the single source which can cause or form the self-reproducing structure of media events (cf. Morgner, 2009). The cultural dimension emphasises the nature of the event, being large-scale or even global, and thus the importance of receiving it abroad.

Consequently, the study selects three cases which appear to display qualities of a maximal distance or contrast, but also might share specific features. The extreme and ordinary thus cover features also represented in other social phenomena. This methodological approach, first proposed by Grounded Theory (drawing on Max Weber's ideal cases, but also comparative methodologies known in functionalism) and nowadays an established principle within qualitative research, enables the analyses to formulate concepts which are not limited to a few phenomena, but which can be generalised and applied to other cases (cf. George \& Bennett, 2005, p. 73 ff).

The selection of the news coverage of these events follows these methodological considerations. The analyses focus on written material (national newspapers and magazines) ${ }^{8}$ and national TV channels (in the case of Malaysia/Singapore, I also consulted radio broadcasts). ${ }^{9}$ Again, the idea was to form a solid case with sufficient material, without the need to analyse all the news footage or printed articles. This material forms the basis for explaining the general construction and formative quality of the audience of media events. The research at this stage is less concerned with describing differences between the different media channels or different regions, but instead aims to conceptualise a general framework. The develop- 
ment of this general framework or basic concepts constrains the presentation of empirical material in great detail but also the presentation of different stages of the analysis of such material (for such a presentation, see Morgner, 2009). The presented extracts are less concerned with providing a set of quantitative evidence, but should closely illustrate, represent or exemplify the inherent concepts. The analysis thus focuses on the semantic structure of the media messages and how they are related to overall formation/structuration of the event (cf. Luhmann, 1980). The semantics of inclusion will address different versions, for instance, inclusion through emotionalised concepts, through forms of co-presence and virtual community, and the function of these semantics.

\section{Semantic inclusions}

The selected events, the Titanic disaster, the assassination of John F. Kennedy, and the death of Princess Diana, bore international repercussions. However, the relationship and involvement of the public did not result from concrete physical damage done to the public itself, as in the case of an earthquake or tsunami. Thus, one wonders through what type of narrative structure found in the mass media does the public become involved, and what public reactions and associations are captured by the mass media? How can cultural differences, as well as differences of age, sex and interest, be overcome?

The thesis addressing these questions is that a similarity relationship in the individual experience of the public is established. In the case of John F. Kennedy, a common reaction was: "It is a tragedy not only for his family, but for all of us" (The Sunday Times, 1963, p. 3). After Princess Diana's death became known, the media delivered statements such as: "In the next few days, her family and the nation must have time to come to terms with this immense loss" (Ngoo, 1997, p. 1). The universal reaction thus consists not of homogeneity, but of a universal heterogeneity. In other words, with the individual relationship, a reference point is established that extends below the level of the differences by which each of us identifies ourselves and those around us: "There is nothing here reflecting a uniform public response [...] the identifications people have with the President [Kennedy] are those that fit their own particular life situations [...], family, religion, character, and basic needs for sustenance and protection" (Barber, 1965, p. 118). The members of the public can identify themselves with an individual attribute that also affects everyone concerned; it is precisely in this manner that a potential universality is attained. For example, the Boston Globe prints a picture of two women at the office of the White Star Line, which is indicated through an advertisement above a desk. A dark-skinned woman wearing simple clothes holds a fairskinned young woman in a marvellous dress and hat who kneels in front of her. The heading says: "The democracy of grief motif: Rich and poor women wait and mourn together" (quoted in Biel, 1996, p. 138)..$^{10}$

This individual and surely personal relationship is formed through the mass media. Within the framework of the media event, this relationsship has the effect on the public of 
creating the impression of a type of actual directness, of a participating intimacy, "... a kind of immediate personal involvement" (Ong, 2002a, p. 502). Nearness and intimacy are generated and are an intrusion into the world of another. "She [Diana] lived in our newspapers; she lived with us every day" (Lyall, 1997, p. A10). As a consequence, the public is directed into a personal relationship of an intimate kind and into a cohesion which enables otherwise unachievable action to become possible. Intimacy is defined as "...the disclosure of emotions and actions which the individual is unlikely to hold up to a wider public gaze" (Giddens, 1992, p. 138). With such generated intimacy, an analogy conclusion, ${ }^{11}$ in the form of a similarity relationship, with reference to the loss of a loved one (passengers, John $\mathrm{F}$. Kennedy, Diana), becomes possible; despite the heterogeneity of the public, a sort of collective relationship is thus created (cf. Zierl, 1992, p. 25ff.; Moore \& Myerhoff, 1994, p. 12). One regrets the loss as if it were a personal, intimate loss. "They were not merely mourning the death of a President in the Irish neighbourhood; they were lamenting the loss of a part of themselves [...] 'It's as if there was a death in every family in Ireland'"' (Talese, 1963, p. 11). A similar reaction is found in the case of Princess Diana: "I feel, like everyone else in this country today, utterly devastated. [...] We are today in a nation in a state of shock" (Hoge, 1997, p. 1).

The similarity relationship thus had a representative modus, in the sense that some aspects are valid for the whole. The press in Malaysia reported in case of the Titanic: "The American people share the sorrow of kinsmen overseas" (The Straits Times, 1912a, p. 7); or "The Kaiser has telegraphed to King George his sympathy, and other expressions of worldwide sympathy have been received" (The Straits Times, 1912b, p. 9). As the word "shared" denotes, it is an occurrence that is experienced both individually and collectively. Common to both these cases was the fact that the occurrence generated an imaginary sense of how it feels to suffer the loss of such a person, such that the loss of a passenger, John F. Kennedy, or Princess Diana became a personal loss. The large-scale event is in this respect also a personal event, inciting regret and grief. ${ }^{12}$ A postman who met housewives after the announcement of John F. Kennedy's death was reported in the press as saying, "They talked about it just as if they had lost their son or daughter" (Berritt, 1963, p. 4). Likewise, the Titanic tragedy affected everybody; nobody remained unaffected, untouched by it: "The news [Titanic disaster] in the Continental capitals has been received with emotion and the utmost sympathy, as people of almost every country have suffered" (The Straits Times, 1912c, p. 7). These events unfold an inclusive quality that serves as a magnet by drawing everything and everybody towards it. "Some of these ceremonies are so all-encompassing that there is nobody left to serve as an out-group. 'We Are the World' is certainly the appropriate theme song for media events" (Dayan \& Katz, 1992, p. 14). ${ }^{13}$

The term "everybody" is understood to mean the sense of the social dimension as a personalised variant of the differentiation between "heterogeneity and homogeneity". This had already been proclaimed by Hugo von Hofmannsthal (cf. Hofmannsthal, 1929). The term "everybody" does not consist of a definite type of person; on the contrary, it concerns 
one who may be well-off, a neighbour, a servant, a loved one, a gambler etc. In relation to the description of a worldwide public, it is precisely this heterogeneity, this internal differentiation of world society, which is captured in this semantic. In this description, society is denoted by the multiplicity in people, roles and forms of address. One distinguishes between professions, gender, age, children and family relationships, celebrities and ordinary people, race etc. They all - and herein lies the speciality of the semantic - remain diverse and heterogeneous, but are nevertheless equally affected by such events. "Everybody came to see the President: workers, office workers, teenagers, school classes".14 In the form of their individuality, everyone is represented in the mass media. ${ }^{15}$ Universality thus consists not of homogeneity, but of universal heterogeneity in the personalised form of "Jedermann" ("Everyman") in relation to the differences between old/young, prominent/unknown, and upper/lower strata. "16 "There [at Princess Diana's funeral] were men and women, young and old, retired people and people taking time off from work" (Lyall, 1997, p. A10). The semantic of the "Everyman" does not mean that such an occurrence is familiar to each individual throughout the world or that it determines his actual mode of thought. "The point, however, is that such phenomena are disembedded from particular places" (Eriksen, 2001, p. 300). Such phenomena occupy a global dimension that can occur everywhere, even when large sections of the world's population are excluded from them. Although the three media events occurred in different historical and cultural settings, an inclusion is constructed through a relationship of similarity. The media event thus speaks to an audience of individuals but consequently to all of them.

\section{Public emotions and the semantics of crying}

As some of the quotes already mention, emotional responses such as grief, crying and hysterical reactions were widely expressed and recognised during these three events. The aim of the study, however, is not to explore the psychological consequences of the events or what such emotions mean for every individual consciousness; rather, the question is more socially motivated and directed towards the construction of the public configuration. Newer literature speaks of "audience making" (cf. Ettema \& Whitney, 1994a). The word "public" is meant not as a summation of individual consciousnesses, ${ }^{17}$ but instead, an imagined category, a semantic which directs the mass communication: "...such audiences [...] exist as relationships within the media" (Ettema \& Whitney, 1994b, p. 6). ${ }^{18}$ The social dimension refers to the duplication of experience possibilities, which means that there is more than one observer, and that these people have to be considered as observers of that observation (cf. Luhmann, 1995, p. 108f.). Consequently, one notes that others observe that which oneself does or does not observe.

The portrayal of lamentation, grief and tears is a variation by which the public itself becomes the bearer or mediator of a large-scale event. The picture of lamentation documents the event, which means that it speaks the language of an event as sudden transforma- 
tion, represents a rapture of attention, and embodies the qualities of an event in a verbatim sense. Simultaneously, through the mass media, individual emotions are portrayed which, as a result, become gathered together into a form of a collective utterance, thereby creating a dense public. ${ }^{19}$

One's tears can hardly be restrained; the need to cry takes possession of the person; in a particular sense, one loses one's restraint, and a rational and objective digestion of the situation is swept into the background (cf. Berkenbusch, 1985, p. 25). "The White Star Line Offices at 9 Broadway were the scene of grief and hysteria. [...] All night long, crowds of grief-stricken relatives and friends besieged the steamship office" (The Globe, 1912, p. 1). In this respect, crying has an "...eruptive character" (Plessner, 1970, p. 23). It simply breaks out of a person, and he or she cannot counter such feelings: "Mayor Richard J. Daley [...] burst into tears when he learned the news [about the assassination of John F. Kennedy] during a luncheon with several associates" (The New York Times, 1963, p. 11). "During the service, some women and a few men could not hold back their tears" (The Straits Times, 1963, p. 11). Crying thus possesses the character of an occurrence, or rather, an event. The public places in which one otherwise restrains one's self from demonstrating strong emotions (such as churches or restaurants) thus become places where emotions are unrestrainedly revealed. The way in which one conducts oneself is marked by an incursion, something that deviates from everyday life. Helmut Plessner (1970, p. 24) remarked that changes of patterns, such as crying, "...interrupt the regulated course of life". In such cases, the event is likewise mirrored. The crying signifies an exception that cannot be trivial or a cause of lesser weight; it is instead meaningful for everybody, particularly for the generation that experienced the suffering (cf. Simons, 1997).

Crying is simultaneously an audio-visual act, which, in its way, has a conspicuous quality. In the case of tears, of course, this becomes visible; crying is an expression that can be neither overlooked nor overheard. It detracts from everyday noises, gesticulations and mimicry (cf. Plessner, 1970, p. 24). It is a sound that overrides every other human tone. Such reactions thus become noticeable for others. One can observe in the cooperative shedding of tears that one is not alone, but instead, is globally united around a collective grief. The individual physical and mental reactions thereby become widely available phenomenon: "Tears and other displays of emotion [...] do not function as an attribute of the individual. They are social indicators of the plight of a group" (Tuchman, 1978, p. 123). In uniting under this symbol, loosely connected individuals become a collective public, mutually sharing the sorrow together. "When we participate in the funeral of a beloved person, we are able to feel the mutual sympathy which the common tears cause, as a silent assent to the significance of the lost, deceased individual" (Stern, 1980, p. 193). In this respect, it is then no longer a single person who laments or sheds tears, but "many", "thousands", and "millions". Crying is, in this respect, individual and, at the same time, collective; everyone cries for him/ herself, and in so doing, all become equal. 
"The people of all nations of the world wept as though one of their own flesh and blood had died" (The Malay Mail, 1963, p. 1). Crying is therefore not just an expression of the pain experienced; rather, the pain is repeated in reflection. In other words, the similarity relationship conveys the sense of loss in the individual personal context of each person. One is therefore dealing with a representative modus which puts one in another's place, or in his shoes. "That we are moved to tears not by our own sufferings, but by those of others, happens in the following way; either in imagination, we put ourselves vividly in the sufferer's place, or we see in his fate the lot of the whole of humanity, and consequently, above all our own fate. Thus, in a very roundabout way, we always weep about ourselves; we feel sympathy with ourselves" (Schopenhauer, 1969, paragraph 67, p. 377). This duplication of perspective creates a feeling in the public of being personally involved, commiserating with the rest of the world, and, in this respect, creating the effect of overcoming the crisis together (cf. Schramm, 1965).

This reduplication of perspectives, this social reflexivity, in turn, is snatched up as a topic in the form of a comparison and collection of reactions from the most diverse regions of the world. The multitude, in its interaction, coalesces in its communicative interrelations with respect to a particular characteristic; everyone is affected, everyone sobs etc. In this way, there is also a consistency to these interactions in various locations. Society in modern times normally manifests itself through a tangible discrepancy between the experiences of individual interaction and social/collective interaction (cf. Luhmann, 1997, p. 826). One does not know instantly what is happening in other interactions at other places and times. But, at the very least, this co-presence becomes changed by a world public and a world event. One can now hear, read or see in other interactions events that similarly transpire or could transpire, and vice versa. To use the interaction among those present under the conditions of a global media event as a model for society would overemphasise the function of this type of social relationship. The interaction's own social reflectivity and its complex mirror relationships cannot be reproduced. Rather, the opportunity to observe others in what they themselves observe is established, in order to likewise note that others perceive one's own observations. With regard to the reactions of the public to such large-scale events as those examined in this article, Walter J. Ong noted: "Part of the overwhelming personal effect was precisely the knowledge that so many others were also personally affected, as they would not have been without television" (Ong, 1967, p. 292). A world media event thus emphasises co-presence, not merely in a type of global, almost "timeless" dissemination of information, but also in the present day; the possibilities for oral interaction become globally simulated (cf. Ong, 1967, pp. 101, 260). The presence of the others enables one to learn: "....in the John F. Kennedy traged(y), the audience could sense its own vast unity" (Ong, 1997, p. 317). Forms of crying or other emotional expressions refer to a semantic inclusion of the audience within the media messages. They are thus not simply mirroring the minds of some people, but constructing a picture of the reactions of the audience, which are a constitutive element of the media event itself. 


\section{Public co-presence}

With the establishment of such reciprocal possibilities of observation, a form of co-presence enters the picture. Within this configuration, the worldwide public experiences a loss of distance, while other interactions incorporate the experience in further interactions and are in turn observed (cf. Ang, 1997). This entails the ability to acquire knowledge of what others experience and naturally, above all, why they experience it in that manner. In this way, the public acquires an integral association: "The integrative status of public tragedy is that somebody standing on the street can cry, and the set of persons who pass him, who don't know him, can know what he's crying about, i.e., he's crying about that public event" (Sacks, 1995, p. 195). ${ }^{20}$

Within such public tragedies, one can express one's feelings in public as well as in private places, and these emotions are available to others; they do not have to avoid looking at the person mourning, since they are aware of the reason for his/her public grief. All of this is possible, although the participants are strangers to each other. One shows emotions as a member of this mass public. "Public tragedies [...] make persons' emotions publicly available and publicly explainable to anonymous parties" (Sacks, 1995, p. 195). In this context, a further phenomenon becomes explainable. People gather in front of newsstands, in front of bulletin boards, on the streets, in front of television shops, in front of town halls, at offices of the White Star Line, on the property of Lyndon B. Johnson or Princess Diana, in churches, temples, synagogues, or mosques, together with those who have a transistor radio, to stand together silently, or else to discuss, to accompany the procession, or to remain on the spot where the shots fell on John F. Kennedy or where Diana's accident happened. Noticeable in all these gatherings is the interaction of strangers. How is it that such interaction, which does not happen as an everyday occurrence, suddenly becomes possible? This type of interaction is manifested where initially no interaction generates itself, but which begins precisely as a result of the interaction (cf. Sacks, 1995, p. 195), such as: "Have you heard?", "It's shocking!", "Is it true?", "Isn't it awful?" etc. Such utterances solve the problem of starting an interaction with a stranger, as these utterances target themselves in an indirect way to others' presence. ${ }^{21}$ The relationship into which the addressee is drawn takes place in reference to the public tragedy, since this also affects the communication partner. The public tragedy is so overwhelming and encompassing that it dominates what one can experience. In the case of a world event (at any rate, in the case of events of such relevance as the three mentioned), the knowledge of this can be presupposed. In this manner, the relationship gains an intimate form and does not have to be elucidated as an entrée. When one hears, "It's shocking," without previously having spoken of the "it", this statement encompasses knowledge of a fact which, in the interaction, is taken for granted. One is thus in a position to reply, in response to this approach, to show that one is also part of the world event being discussed. By means of such utterances, one's own perplexity over the tragedy is articulated, and one recognises that this applies to the other also. The interaction is thus pre-structured to a high degree and is in no way coincidental and as innocuous as a "hello" might be. It 
then becomes unproblematic to initiate contact with strangers and to assemble in public places. Such interaction is then snatched up by the mass media as an expression of collective participation in an event. The same occurrence has a similar effect on many individual witnesses at almost the same time, generating similar reactions in public. The collective possibility of experience generates a relationship. This communication is therefore not limited to the private sphere, but instead finds a unifying effect in processions, festivities and in mass gatherings of people. The individual manifestations turn into one of concentrated expression in which one steps out of the individual and into the collective world sphere.

The media events construct their audiences in the form of a virtual community, where one can observe others, and observe that one is being observed, and where the event is shared by many. The event has a collective nature, although the viewers remain unknown to each other. We can refer at this point to an idea of Anthony Giddens (1984), who proposes that social integration requires co-presence. Forms of interaction can organise social integration through nearness and familiarity, but in complex social systems, like the mass media, the social integration cannot organise the system integration. Distant messages and accounts cannot be integrated or regulated through specialised roles within interactive settings. The mass media organise their system integration through media of dissemination or forms of recording and planning within their organisations. As a consequence, the interaction as a requirement for friendship, love and intimacy is then even more highlighted, since it need not organise all societal processes. Nevertheless, the large-scale media events analysed in this article demonstrate that the mass media are able within very limited temporal settings to coordinate distant processes in a dense manner and thus simulate a form of global interaction. As a consequence, emotions of intimacy are awakened and one weeps around the globe for the loss of John F. Kennedy or Princess Diana, we cry and mourn with their relatives, and we are deeply touched when John Jr. says farewell to the coffin of his late father. A nearness and familiarity are created, which reminds us of the concept of the "global village".

\section{The function of the public}

These aspects of the reaction pattern and the inclusion form address the questions regarding the function of the duplication of public experience possibilities in relation to the mass media. This perspective provides a different approach to the concept of the audience, highlighting aspects which go beyond socio-psychological approaches to the audience. The system-theoretical discussion in this sphere disassociates itself from descriptions of the public as a collection of psychical situations, individual means of communication etc. (cf. Luhmann, 1990). These considerations reach back to the metaphor of the mirror, as utilised in the work of Harrison C. White (1981, p. 543ff.). What one sees in the mirror is not a virtuous mirror image of one's better self; instead, the image concerns the possibility of how the observer sees himself and how he observes others. One sees in the mirror only a portion 
of the face to whom one turns. At the same time, one sees not only oneself, but looking over one's shoulder, one sees the reactions of others who are also positioned and acting in front of the mirror; these observations relate to complicated, very indirect observation relationships. Rudolf Stichweh (2003) thus speaks of a second-order mirror. One looks at the other in the mirror, observes how the other observes the corresponding system, and through this observation, the system extracts other information about itself. The mirror effect refers to its opaqueness, hence to the disassociation from that which appears in the multitude of consciousness systems. ${ }^{22}$ This means the mass media sees itself reflected in the public, whilst simultaneously seeing more or less a reflection of a beholder. In this sense, one can speak of a two-sided mirror, whereby each mirror faces the other. For the public, this generates the function of positive or negative feedback, an amplifier or a suppressive role. $^{23}$ In the case of sorrow, the event is repeated once more in the public and, in so doing, is thus reflected and amplified. Since the mass media generally prefer fresh information, their repetition of disruptive news serves to emphasise its extravagance, its singularity, and its extraordinary nature. The public enables this fixation on particular topics, and it is precisely this obsession which emphasises that the reverse case is possible; that one can switch attention to other scenes, topics, reports etc. (cf. Lang \& Lang, 1983, p. 22). 24 "A public may last only for the moment of routine salutations at a gathering, or it may last for hours of joint immersion before a communal TV." Harrison C. White (1995, p. 1054) speaks similarly in relation to the public of "network switchings". This indifference accompanies all types of mass communication. In relation to events, the public can thus either be enthusiastic about events or find them boring; what is amusing for one is a testimony of decadence for someone else. In the public mirror, there thus runs a controlling thread in all the means of mass communication. On one occasion it is direct, whilst on another occasion it is rather indirect; it can supply relevance or not, or it can concentrate attention or can allow it to decline and divert to other topics. ${ }^{25}$ Within this public configuration, the mass media are responsible for diversity in the public; they possess the power to allow topics to decline relentlessly (cf. Cantor, 1994, p. 166). Here, one has to reckon with the fourth power (cf. Baecker, 2004).

\section{References}

Amazement and dismay (1912: c, 19. April). The Straits Times, p. 7.

Ang, I. (1997) (Ed.). Planet Diana: Cultural Studies and Global Mourning (Research Centre in Intercommunal Studies). Kingswood: University of Western Sydney Press.

Baecker, D. (2004). Die vierte Gewalt: Massenmedien und Demokratieverständnis. Funkkorrespondenz, Beilage zu Nr. 8-9, [The fourth power: Mass media and democratic understanding]. 20 February, 4-9.

Barber, J.D. (1965). Peer group discussion and recovery from the Kennedy assassination. In B. Greenberg \& E.P. Parker (Eds.), The Kennedy assassination and the American public: Social communication in crisis (pp. 112-129). Stanford, Cal: Stanford University Press. 
Barton, A.H. et al. (1963). Social Organization under Stress - A Sociological Review of Disaster Studies. Washington: National Academy of Sciences-National Research Council.

Berelson, B. (1949). Events as an influence upon public opinion. Journalism Quarterly, 26, 145-148.

Berger, P.L. \& Luckmann T. (1967). The Social Construction of Reality. A Treatise in the Sociology of Knowledge. New York: Anchor Books.

Berkenbusch, G. (1985). Zum Heulen: Kulturgeschichte unserer Tränen [Crying: A cultural history of our tears]. Berlin: Transit Buchverlag.

Berritt, G. (1963, 23 November). Cities muffled as news spreads. Men say 'My God'. Shoppers stop to pray and many businesses close. The New York Times, p. 4.

Berscheid, E. (1987). Emotion and interpersonal communication. In E. M. Rohloff \& Miller, G.R. (Eds), Interpersonal processes: New directions in communication research (pp.77-88). Newbury Park, London, New Delhi: Sage Publications.

Biel, S. (1996). Down with the Old Canoe: A Cultural History of the Titanic Disaster. New York, London: W.W. Norton.

Bourdieu, P. (1995). Public opinion does not exist. In P. Bourdieu, Sociology in Question (pp.149-57). London: Sage.

Bourdieu, P. (1999). On Television. New York: New Press.

Butsch, R. (2000). The Making of American Audiences: From the Stage to Television, 1750-1990. Cambridge: Cambridge University Press.

Cantor, M. (1994). The role of the audience in the production of culture: a personal research retrospective. In J.S. Ettema, James S. \& D.C. Whitney (Eds.), Audiencemaking: How the Media Create the Audience (pp.149-70), Thousand Oaks, London, New Delhi: Sage Publications.

Cantril, H. (1960[1940]). The Invasion from Mars: A Study in the Psychology of Panic. New York: Harper Torchbooks.

Curran, J. \& Liebes, T. (1998) (Eds.). Media, Ritual and Identity. London: Routledge.

Dayan, D. \& Katz, E (1992). Media Events: The Live Broadcasting of History. Cambridge: Harvard University Press.

Epstein, E.J. (1974). News from Nowhere: Television and News. New York: Vintage Books.

Eriksen, T.H. (2001). Small Places, Large Issues: An Introduction to Social and Cultural Anthropology (2nd edition). London, Sterlin, Virginia: Pluto Press.

Ettema, J.S. \& Whitney D.C. (1994: a) (Eds). Audiencemaking: How the Media Create the Audience. Thousand Oaks, London, New Delhi: Sage Publications.

Ettema, J.S. \& Whitney D.C. (1994: b). The money arrow: An introduction to audiencemaking. In J.S. Ettema \& D.C. Whitney (Eds), Audiencemaking: How the Media Create the Audience (pp.1-18), Thousand Oaks, London, New Delhi: Sage Publications.

George, A.L. \& Bennett A. (2005). Case Studies and Theory Development in the Social Sciences. Cambridge: The MIT Press

Giddens, A. (1984). The Constitution of Society. Outline of the Theory of Structuration. Cambridge: Polity Press.

Giddens, A. (1992). The Transformation of Intimacy: Sexuality, Love, and Eroticism in Modern Societies. Stanford; California: Stanford University Press.

Glaser, B.G. \& Strauss, A.L. (1967). The Discovery of Grounded Theory: Strategies for Qualitative Research. New York: Aldine de Gruyter.

Hofmannsthal, H. (1929). The Salzburg Everymen: The Play of the Rich Man's Death as Acted Before the Cathedral at Salzburg. Salzburg: Mora. 
Hoge, W. (1997, 1 September). Fighting back tears, Tony Blair talks of nations' shock. The New York Times, p.1.

Kennedy inspired the world to strive for peace and progress (1963, 30 November). The Malay Mail, p. 1.

Kepplinger, H.M. \& Habermeier, J. (1995). The impact of key events on the presentation of reality. European Journal of Communication, 10, 371-390.

Kepplinger, H.M. \& Roth H. (1979). Creating a crisis: German mass media and oil supply in 1973-74. Public Opinion Quarterly, 43, 285-296.

Lang, G.E. \& Lang K. (1983). The Battle for Public Opinion. The President, the Press, and the Polls during Watergate. New York: Columbia University Press.

Luhmann, N. (1980). Gesellschaftsstruktur und Semantik [Social structure and semantic. Studies in the sociology of knowledge]. Studien zur Wissenssoziologie, Vol. 1. Frankfurt am Main: Suhrkamp.

Luhmann, N. (1990). Societal complexity and public opinion. In N. Luhmann, Political Theory in the Welfares State (pp.203-18). Berlin, New York: De Gruyter.

Luhmann, N. (1995). Social Systems. Stanford: Stanford University Press.

Luhmann, N. (1997). Die Gesellschaft der Gesellschaft [The Society of Society], 2 Volumes. Frankfurt am Main: Suhrkamp.

Lyall, S. (1997, 2 September). In word and deed, Londoners mourn a family member. The New York Times, p. A10.

McQuail, D. (1969). Uncertainty about the audience and the organization of mass communication. In P. Halmos (Ed.), The Sociology of Mass Media Communicators (The Sociological Review 13, pp.75-84). Keele, Staffordshire: University of Keele.

McQuail, D., Blumler J.G. \& Brown, J.R. (1972). The television audience: A revised perspective In D. McQuail (Ed.), Sociology of Mass Communications (pp.135-65), Harmondsworth: Penguin Books Ltd.

Molotch, H.L. \& Lester, M.J. (1974). News as Purpose Behaviour. American Sociological Review, 39, 101-112.

Moore, S.F. \& Myerhoff. B.G. (1994). Introduction: Secular ritual, forms and meanings. In S.F. Moore \& B.G. Myerhoff (Eds), Secular Ritual (pp.3-24). Assen: Van Gorcum.

Morgner, C. (2008). Zeitlichkeiten globaler Medienereignisse - Am Beispiel der Ermordung John F. Kennedys, [Temporality of global media events - looking at the assassination of John F. Kennedy]. In F. Lenger \& A. Nünning (Eds.), Medienereignisse der Moderne (pp. 130-149). Darmstadt: WBG.

Morgner, C. (2009). Weltereignisse und Massenmedien. Zur Theorie des Weltmedienereignisses. Studien zur Titanic, John F. Kennedy und Lady Diana [World Events and Mass Media. Towards a Theory of World Media Events]. Bielefeld: transcript.

Ngoo, I. (1997, 1. September). S'pore 'shocked and saddened' by Diana's death. The Straits Times, p. 1.

Ong, W.J. (1967). The Presence of the Word. Some Prolegomena for Cultural and Religious History. New Haven, London: Yale University Press.

Ong, W.J. (1997). Interfaces of the Word: Studies in the Evolution of Consciousness and Culture. Ithaca, London: Cornell University Press.

Ong, W.J. (2002: a). Technological development and writer-subject-reader immediacies. In T.J. Farrell \& P.A. Soukup (eds.), An Ong Reader: Challenge for Further Enquiry (pp.497-504). Cresskill, New Jersey: Hampton Press Inc.

Ong, W. J. (2002: b). The writer's audience is always a fiction. In T.J. Farrell \& P.A. Soukup (eds.), An Ong reader: Challenge for Further Enquiry (pp.405-427). Cresskill, New Jersey: Hampton Press Inc.

People across U.S. voice grief and revulsion (1963, 23 November). The New York Times, p. 11.

Picture of grief (1963, 25 November). The Straits Times, p. 11.

Plessner, H. (1970). Laughing and Crying: A Study of the Limits of Human Behaviour. Evanston: Northwestern University Press. 
Rieffel, R. (2005). Que sont les Médias? Paris: Edition Gallimard.

Sacks, H. (1995) Lectures on Conversation (Published by von Gail Jefferson), Volume 2. Malden, Oxford, Victoria: Blackwell Publishing.

Schenk, G.J. (2007). Historical disaster research. State of research, concepts, methods and case studies. Historical Social Research (Special Issue: Historical Disaster Research - Concepts, Methods and Case Studies), 21, 9-31.

Schopenhauer, A. (1969). The World as Will and Representation, Vol. 1. New York: Dover Publications.

Schramm, W. (1965). Communication in crisis. In B.S. Greenburg \& E. Parker (Eds.), The Kennedy Assassination and the American Public. Social Communication in Crisis (pp.1-25), Stanford, Cal: Stanford University Press.

Simons, J. (1997). The dialectics of Diana as empty signifier. Theory \& Event, 1, 7pp.

Stäheli, U. (2000). Fatal attraction. Popular modes of inclusion in the economic system. In U. Stäheli \& R. Stichweh (Eds), Inclusion/Exclusion and Socio-cultural Identities (Special Issue: Soziale Systeme, Zeitschrift für soziologische Theorie [Social Systems, Journal for Sociological Theories]. 8, 110-23.

Stäheli, U. (2003). The popular in the political system. Cultural Studies. 17, 275-99.

Steenveld, L. \& Strelitz L. (1998). The 1995 Rugby World Cup and the Politics of Nation-building in South Africa. Media, Culture \& Society, 20, 609-629.

Stern, A. (1980). Philosophie des Lachens und Weinens [Philosophy of Laughing and Crying]. Vienna, Munich: R. Oldenburg Verlag.

Stichweh, R. (2003). The genesis of a global public sphere. Development, 46, 26-29.

Talese, G. (1963, 24 November). In south Boston, angry silence reflects the passing of a hero. The New York Times, p. 11.

The Kaiser's sympathy (1912: b, 19. April). The Straits Times, p. 9.

The world reacts with horror: Messages of grief pour in from all over the globe (1963, 24 November). The Sunday Times, p. 3.

Thompson, J.B. (1995). The Media and the Modernity: A Social Theory of the Media. Cambridge, Oxford: Stanford University Press.

Titanic disaster (1912: a, 19. April). The Straits Times, p. 7.

Tränen [tears] (1963, 25. November), Frankfurter Allgemeine Zeitung (1963), p. 1.

Tuchman, G. (1978). Making News: A Study in the Construction of Reality. New York: The Free Press.

Turley, R.O. (1969). An Analysis of the Mexican Reaction to the Assassination of John F. Kennedy: A Study in Cross-cultural Attitudes (Master's thesis). Michigan State University.

White, H.C. (1981). Where do markets come from? American Journal of Sociology, 87, 517-547.

White, H.C. (1995). Network switchings and Bayesian forks: Reconstructing the social and behavioral sciences. Social Research, 62, 1035-63.

Women collapse in frantic crowd that prays for good news (1912, 16 April). The Globe, p. 1.

\section{Notes}

1. I am grateful to Nicolai Jørgensgaard Graakjær and the two anonymous reviewers for their comments and help.

2. Thompson (1995, p. 26) therefore suggests speaking of "mediated communication" or "the media" in order to open up the semantic for another understanding.

3. Thus, we have to be very careful when using the terms "mass media" or "mass communication", because they designate two different aspects: the media as a form of technology and the media as a 
specific type of message or communication, for example, in contrast to political or medical communication (cf. Rieffel, 2005, p. 31).

4. Pierre Bourdieu highlights this self-referential modus operandi as well when he speaks of a "circular circulation of information" (cf. Bourdieu, 1999, p. 23 ff).

5. The classical study here is Barton (1963). Robert Osborne Turley quotes an inventory of a disaster research group which lists 114 studies about 103 events, including airplane crashes, blizzards, earthquakes, volcanoes, epidemics, explosions and fires, false alerts, floods, hurricanes and typhoons, mine disasters, tornadoes, toxicological substances, and bombings in wars (cf. Turley, 1969, p. 9).

6. The selection of the cases is strictly technical. It is not influenced by a pre-configured conception of what they are or what they are about. The aim was to provide a basis for alternation through the material, which should inform the development of a general framework. The modus operandi of this research process has a circular order (cf. Glaser \& Strauss, 1967). The analysis needs to return back and forth between the empirical data and developing theory, so that they both can stimulate each other.

7. In addition and to my surprise, the actual media coverage of these events has never been of great interest, and only a few studies analysing some aspects of it have been published.

8. This included the New York Times, Life Magazine (U.S.), FAZ, Der Spiegel (Germany), The Straits Times, and Malay Mail (Singapore/Federation Malaysia). Several hundred newspaper articles of different lengths mostly of the first days or week were selected and analysed.

9. The TV footage of the channels NBC (U.S.), ARD (Germany) and Channel 5 of TV Malaysia Singapura of the first days or week were analysed, which consisted of more than 40 hours of TV coverage.

10. This semantic has changed over time. The Titanic disaster is marked by a concept of class inclusion. From the bottom to the top of society, everybody is affected, which is also graphically illustrated. The assassination of John F. Kennedy and death of Lady Diana refer to different categories of self-description, for instance, different professions, sexes or age groups. They may already use social science's categories or modern day programming criteria, like programmes for specific age groups.

11. Thus, in connection with the deliberations of Berger and Luckmann (1967, p. 53f.).

12. In the case of Diana, see, for example, the headline "Londoners mourn a family member" (Lyall, 1997, p. A10).

13. As opposed to Dayan and Katz, this does not concern the question of the social-physiological consequences for the public of such media events in the foreground (1992 p. 134ff.), but instead, which constitutive contribution forms the social dimension to the formation of this world event.

14. NBC archived television footage, Reel $5,22.11 .1963$ at 04:53.

15. Mainly due to copyright reasons, no visual material could be included in this text, but all three events make intense use of it, whether in the form of early photography, collages or graphical representations, or computer generated visual representations. However, also with the advent of new technologies, the written word does not disappear, but it seems that text and picture are brought into one narrative strategy, where the text leads to some peak point which is captured in some sort of visual representation.

16. In this respect, it does not mean that other semantics of this type are not possible. One recalls here the 2006 Football World Cup Championship in Germany, which, in terms of friendly relationships (as guests among friends), consisted of a semantic of interaction.

17. Pierre Bourdieu comes to a similar conclusion and objects to the necessity of taking into account both virtual disposition and the formation of pressure groups, and hence of "audiencemaking" (cf. Bourdieu, 1995).

18. In this respect, the public semantic offers not only the orientation possibilities for the producers of TV programmes, but also for the audience. The generation of TV programmes makes it possible to pro- 
duce theme-oriented reports (family programmes, sports programmes etc.), which serve to orient the producers and to which the public can form a corresponding preference for particular programmes (cf. Butsch, 2000, p. 197).

19. This sheds new light on the media's interest in emotive issues. They do not simply refer to some sort of media frenzy, but function as a very basic form of inclusion. In particular, large-scale media events will refer to this semantic, since it addresses a possible global public.

20. The following extract is thus significantly inspired by the explanations of Harvey Sacks.

21. This also applies in this respect to the opening of interaction among acquaintances, when important matters of this type are uppermost in everyone's minds, when one can assume that one is speaking of known events, and when customary conversational openings can be set aside, thus enabling interaction.

22. In any case, a comprehensive portion is excluded, for only by doing so does the possibility arise of gaining results, which serve as orientation (cf. McQuail, 1969).

23. This applies also to organisations, and particularly, to competitors seen in the mirror: "Major news developments" are those for which it "[...] can be expected the competing media will report" (Epstein, 1974, p. 193).

24. A prerequisite for this is that the participation of the public is typical for a democratic vote, with only limited or no obligations whatsoever, in relation to the TV station or newspapers, as well as other portions of the public (cf. McQuail et al., 1972, p. 138).

25. By the public here is meant that for someone, something is written or transmitted, and that people exist who will either read or view it. This image of the reader or viewer is encompassed in the means of communication; and here, the reader is imagined and conversely fictionalised in the story. The public thus orients itself not only with the creator, but also with the recipient (cf. the familiar topic by Ong, 2002b, pp. 409, 411)

Dr Christian Morgner

Assistant Professor

Department of Sociology

University of Lucerne, Switzerland

christian.morgner@unilu.ch 